\title{
Medicinal plants with potential antihypertensive properties: emphasis on natural products from the Brazilian Cerrado ${ }^{1}$
}

\author{
(D) Marcelo Antônio da Trindade 2 , (DEernanda Cardoso da Silva ${ }^{3}$, Bruna Juber de Araújo ${ }^{3}$, \\ (D) $\underline{\text { Janayne Luihan Silva }}^{4}$, (DThaise Gonçalves de Araújo ${ }^{3}$ and ${ }^{\text {Cristina Ribas Fürstenau }}{ }^{5,6}$
}

\begin{abstract}
How to cite: Trindade, M. A., Silva, F. C., Araújo B. J., Silva J. L., Araújo T. G., \& Fürstenau C. R. 2021. Medicinal plants with potential antihypertensive properties: emphasis on natural products from the Brazilian Cerrado. Hoehnea 49: e1232020. https://doi.org/10.1590/2236-8906-123/2020
\end{abstract}

\begin{abstract}
Medicinal plants with potential antihypertensive properties: emphasis on natural products from the Brazilian Cerrado). Arterial hypertension is a worldwide public health problem and the search for new medicines is one of the biggest challenges for the treatment of this pathology. Secondary metabolites of plants exhibit pharmacological properties of great phyto therapeutic interest. Cerrado is one of the largest biomes in Brazil and research with Cerrado plants as therapeutic resources is of growing interest. Our objective was to compile data regarding the Cerrado plants that already have some of their active compounds described and may potentially be used to treat arterial hypertension. We concluded that flavonoids, tannins, steroids and saponins exhibit important properties to low blood pressure. Thus, the species from Cerrado Brazilian such as pau-paraíba (Simarouba versicolor), pau-santo (Kielmeyera coriacea), abiu-do-cerrado (Pouteria torta), guarandi (Calophyllum brasiliense), bacaba (Oenocarpus bacaba), puçá-amarelo (Mouriri elliptica), fava-de-anta (Dimorphandramollis), murici (Byrsonima crassifolia) and cereja-do-cerrado (Eugenia calycina) are strong candidates for future herbal studies in this field.
\end{abstract}

Keywords: antihypertensive plants, Brazilian Savanna, hypertension, plant secondary metabolites, phytotherapy

RESUMO - (Plantas medicinais com potenciais propriedades anti-hipertensivas: ênfase em produtos naturais do Cerrado Brasileiro). A hipertensão arterial é um problema de saúde pública mundial e a busca por novos medicamentos é um dos maiores desafios para o tratamento dessa patologia. Os metabólitos secundários das plantas apresentam propriedades farmacológicas de grande interesse fitoterápico. O Cerrado é um dos maiores biomas do Brasil e cresce o interesse em pesquisas com plantas desta região como recurso terapêutico. Nosso objetivo foi compilar dados sobre as plantas do Cerrado que já possuem alguns de seus compostos ativos descritos e que podem ser potencialmente utilizadas no tratamento da hipertensão arterial. Concluímos que flavonóides, taninos, esteróides e saponinas apresentam propriedades importantes para a redução da pressão arterial. Assim, as espécies do Cerrado brasileiro, pau-paraíba (Simarouba versicolor), pau-santo (Kielmeyera coriacea), abiu-do-cerrado (Pouteria torta), guarandi (Calophyllum brasiliense), bacaba (Oenocarpus bacaba), puçá-amarelo (Mouriri eliptica), fava-de-anta (Dimorphandramollis), murici (Byrsonima crassifolia) e cereja-do-cerrado (Eugenia calycina) são fortes candidatas para futuros estudos fitoterápicos.

Palavras-chave: fitoterapia, hipertensão, metabólitos secundários de plantas, plantas anti-hipertensivas, savana brasileira

\section{Introduction}

Systemic arterial hypertension (SAH) is characterized by the sustained maintenance of blood pressure (BP) above 130 and $139 \mathrm{mmHg}$ for systolic and/or $80 \mathrm{mmHg}$ for diastolic blood pressure. The causes of SAH range from genetic, metabolic, behavioral factors and may even be caused by pathophysiological changes in other organs (Précoma et al. 2019).

Given the different factors involved in the triggering of $\mathrm{SAH}$, it is expected that several signaling pathways are involved in the regulation of $\mathrm{BP}$ and that dysregulation in those pathways are associated to SAH. Among the pathways involved in BP control, nitric oxide (NO), angiotensin II and

1. Part of a Work for Completion of Course by first Author

2. Universidade Federal de Lavras, Instituto de Ciências Naturais, Avenida Doutor Sílvio Menicucci, s/n, Bairro Ignácio Valentin, 37200-900 Lavras, MG, Brasil

3. Universidade Federal de Uberlândia, Instituto de Biotecnologia, Avenida Getúlio Vargas, 230, Bairro Centro, 38700-128 Patos de Minas, MG, Brasil 4. Universidade Federal de Minas Gerais, Instituto de Ciências Biológicas, Avenida Presidente Antônio Carlos, 6627, Bairro Pampulha, $31270-$ 901 Belo Horizonte, MG, Brasil

5. Universidade Federal do ABC, Centro de Ciências Naturais e Humanas, Avenida dos Estados, 5001, Bairro Bangú, 09280-550 Santo André, SP, Brasil

6. Corresponding author: c.furstenau@ufabc.edu.br the production of reactive oxygen species (ROS) occupy prominent place (Förstermann et al. 2017).

The ideal treatment for SAH depends on the causes of the disease and on the patient's response (Malachias et al. 2016). Currently, drug resistant SAH has been a concern, as it has become more and more frequent. Also, the available drugs or their combination may not be effective for the treatment and many patients may present a silent evolution of symptoms, which may cause other cardiovascular diseases and culminate in death (Pijacka et al. 2016, Pike et al. 2017).

In this way, there is a growing interest in developing research focused at identifying new approaches for $\mathrm{SAH}$ treatment. The use of herbal medicines has increased in recent years which leveraged the research on the identification and characterization of bioactive molecules (Lorenzi \& Matos 
2003, Barbosa et al. 2012). Plants from the Brazilian Cerrado are recognized by the population for their wide application in home medicine and research has shown that some of these species present compounds that can provide BP by distinct mechanisms (Pereira \& Cardoso 2012, Silva et al. 2010). Therefore, the present Review aimed to compile results from different studies that point out to the anti-hypertensive and regulatory potential of some Brazilian Cerrado plants.

\section{Material and Methods}

This study is a systematic review of the literature. Searches were performed in the following databases: PubMed, Periódicos CAPES and Google Scholar. Articles published in the last 20 years (from 2000 to 2020) were selected, except for prestigious works in the area, which were used regardless of the publication date. Works published in English, Portuguese or Spanish were considered.

References were searched for the terms in association "Systemic Arterial Hypertension", "Brazilian Cerrado", "Medicinal plants" and "Antihypertensive action" without the use of controlled vocabulary (descriptors). With this strategy, there was a recovery of a greater number of references, ensuring the detection of most of the works published within the preestablished criteria.

Review and original articles with experimental design (clinical trials, randomized or not) and observational studies, which studied the use of Cerrado plants to reduce blood pressure or treat hypertension in vitro and/ or in vivo were considered. Duplicate references (present in more than one database), outside the topic of interest and those that did not meet the criteria defined above were excluded.

The total number of articles found in the three databases with the combinations of terms was 2044: 68 in the PubMed platform, 26 in CAPES Journals and 1950 inside Google Scholar. Of this total, 1943 were excluded for not meeting the criteria previously defined. Finally, 101 eligible references containing the most cited Cerrado species exhibiting some antihypertensive properties were selected to compose the present Review with the additional descriptions presented.

\section{Results}

Systemic Arterial Hypertension - According to a survey by the World Health Organization (WHO) cited by the Brazilian Society of Cardiology (Précoma et al. 2019), systemic arterial hypertension $(\mathrm{SAH})$ is responsible for 7.5 million premature and preventable deaths worldwide, being the main risk factor for several complications related to the development of cardiovascular diseases, such as stroke, acute myocardial infarction, heart failure, peripheral arterial disease and chronic kidney disease (Malachias et al. 2016). About $30 \%$ of the general Brazilian population is affected by $\mathrm{SAH}$, generating a strong impact on the deaths caused by its complications and a challenge for public health (Précoma et al. 2019).

$\mathrm{SAH}$ is related to different factors like advanced age (Li et al. 2018, Mendes et al. 2014); genetic predisposition (Whelton et al. 2017); functional and/ or structural changes in target organs such as kidneys, arteries, heart, and brain (Cesar et al. 2014); changes in metabolism, overweight, poor diet and physical inactivity and drugs and pharmaceuticals (Bloch et al. 2016, Malachias et al. 2016). In physiological terms, $\mathrm{SAH}$ is the result of homeostatic loss between two determining factors: the volume of blood pumped by the heart in one minute (cardiac output) and the resistance of blood vessels, especially arterioles, to blood flow (systemic or peripheral vascular resistance) (Krieger et al. 1996), resulting in the loss of the ability of the endothelium to normally vasodilate (Cohen 2007). Such pathology is continuously influenced by complex pressure systems (as the sympathetic nervous system, catecholamines, angiotensin, endothelin, etc.) and depressants (as nitric oxide (NO), bradykinin, etc.) (Krieger et al. 1996).

The initial stage (stage 1) of SAH is characterized by the sustained elevation of systemic blood pressure, with values between 130 and $139 \mathrm{mmHg}$ for systolic blood pressure and/ or $80 \mathrm{mmHg}$ for diastolic blood pressure. At a more advanced stage (stage 2), these values can exceed $140 \mathrm{mmHg}$ for systolic pressure and $90 \mathrm{mmHg}$ for diastolic pressure (Whelton et al. 2017). The individual affected by primary SAH (also called essential hypertension), that is, unrelated to other pathologies, is usually asymptomatic; however, some patients may experience suboccipital headache, drowsiness, visual disturbance, nausea, tinnitus, and fatigue. In turn, the person affected by secondary $\mathrm{SAH}$, which is related to other pathologies, can present a diversity of symptoms associated with the initial pathology (Oigman 2014).

The major concern related to hypertension is the fact that it evolves silently, and most of the affected people are only diagnosed after crises and hypertensive emergencies (Freitas Filho et al. 2017). Then, early diagnosis is essential to prevent possible complications. The measurement of blood pressure (BP) levels is done at the doctor's office in all consultations, using manual, semi-automatic or automatic sphygmomanometers. Outside the office, BP can be measured using residential BP measurement (RBPM) and/ or 24-hour ambulatory BP measurement (ABPM), with ABPM allowing BP measurement in moments of sleep and wakefulness (Malachias et al. 2016).

Blood pressure assessments are used to classify the BP condition in normotensive - BP levels within those considered normal; prehypertension - BP values close to the recommended upper limit; stage 1 hypertension and stage 2 hypertension - BP levels above normal. After diagnosis, the best form of treatment is defined, which can be non-medicated and/ or medicated (Malachias et al. 2016, Whelton et al. 2017).

Signaling pathways activated during arterial hypertension - The SAH manifests itself in response to the activation of some cell signaling pathways, which involve endothelial dysfunction, vascular remodeling, and immune infiltration, with a consequent increase in the production of reactive oxygen species (ROS) (Roy et al. 2018). Thus, some signaling pathways are more frequently activated or inhibited in this pathology, such as the NO pathway, angiotensin II and the production of ROS (Förstermann et al. 2017).

The endothelium plays an important role in the vasculature, being responsible for the synthesis of vasomotor molecules such as NO (Carvalho et al. 2001), which plays an important vasodilating action (Piotrkowski et al. 2015) by inhibiting the entry of calcium ions $\left(\mathrm{Ca}^{+}\right)$inside the cell (Moneer et al. 2003). Because of endothelial dysfunction in hypertension there is an imbalance in the production and release of vasomotor molecules, including a decrease in the release of $\mathrm{NO}$, an increase in ROS and the consequent increase in vascular tone (Carvalho et al. 2001).

Angiotensin II presents different actions that influence blood pressure levels. On one hand, it has a direct vasoconstrictor action, 
acting via AT1 receptors present in vascular smooth muscle; on the other hand, it activates the secretion of aldosterone, an antidiuretic hormone, which reduces the excretion of water and salts, increasing vascular tone (Lima et al. 2007). In 1996, the hypertensive action of angiotensin II was characterized by activating the production of superoxide via membrane NADH/ NADPH, causing oxidative stress (Rajagopalan et al. 1996). In addition, in 2001 it was discovered that this molecule also stimulates collagen secretion through the activation of type 1 receptors. Therefore, activation of the angiotensin II pathway is one of the characteristics of SAH (Lijnen et al. 2001, Li et al. 2016).

The production of ROS in moderate concentrations has an important signaling role, helping to maintain homeostasis in physiological conditions. The excessive and sustained production of these molecules, however, concomitant with the low availability of antioxidant agents, leads to oxidative stress (Förstermann et al. 2017). Oxidative stress is characterized by the high reactivity of ROS that cause the degradation of cellular components and initiate degradative processes (Bonomini et al. 2015). In the cardiovascular system, NADPH oxidases and mitochondrial oxidases produce ROS; and, evidence shows that, during hypertension, this production is increased, contributing to the symptoms of the disease (Harrison \& Gongora 2009, Sinha \& Kumar Dabla 2015).

As a result of the participation of these signaling pathways in the development of SAH, the antihypertensive effects of many drugs and medicinal plants are observed from their regulation.

Antihypertensive therapies available - The choice of the therapeutic approach for SAH depends on the stage of hypertension and the cardiovascular risks associated with it and can include everything from non-medication until the use of antihypertensive drugs. The treatment aims to reduce BP to levels close to normal, to protect target organs from injuries and/ or changes caused by high BP and to prevent outcomes of cardiovascular and renal damage (Malachias et al. 2016).

Non-drug approaches can be effective in preventing SAH and reducing BP, but they are limited to patient compliance in the medium and long term. In addition, these interventions may assist in the effectiveness of drug treatment (Malachias et al. 2016, Whelton et al. 2017). Non-drug approaches mainly involve changes in eating habits and adherence to physical activity (Kohlmann Júnior et al. 1999). Thus, non-drug treatments include weight loss for overweight or obese people, adherence to a healthy diet such as DASH (Dietary Approaches to Stop Hypertension), reduced sodium intake, potassium supplementation, adherence to physical activities (of 90 to 150 minutes per week), moderation in the consumption of alcoholic beverages and smoking and stress control (Malachias et al. 2016, Freitas Filho et al. 2017, Whelton et al. 2017).

Drug treatment, in turn, aims to reduce BP levels more efficiently and prevent/ treat cardiovascular risks. Among the main classes of current antihypertensive drugs used are angiotensin-converting enzyme (ACE) inhibitors, angiotensin AT1 receptor blockers, diuretics, calcium channel blockers, beta-blockers, alpha-blockers, centrally acting sympatholytics, direct vasodilators and antagonists' mineralocorticoids (Cesar et al. 2014).

In general, ACE inhibitors work by blocking the formation of angiotensin II, increasing the availability, and reducing the degradation of vasodilators. AT1 receptor blockers also inhibit the vasoconstrictor effect activated by the renin-angiotensin system. Diuretics, in turn, act on the nephrons, increasing the excretion of sodium and reducing its concentration in the circulation and, consequently, the levels of blood pressure (Cesar et al. 2014).

Calcium channel blockers act by reducing the entry of calcium into smooth muscle cells in arterioles, thus decreasing the contraction of these cells and peripheral vascular resistance. Beta-blockers act by blocking the action of catecholamines on $\beta$ receptors, causing vasodilation and reducing cardiac output. Alpha-blockers act as competitive antagonists of $\alpha$ receptors, blocking the action of catecholamines and reducing peripheral vascular resistance (Malachias et al. 2016).

The centrally acting sympatholytics act directly on the central nervous system (CNS), reducing sympathetic influx and is reserved as one of the last drugs of choice for having a direct action on the CNS (Cesar et al. 2014, Whelton et al. 2017). Besides, direct vasodilators cause vasodilation, but are not used as monotherapy, they are generally associated with the administration of diuretics because they lead to sodium and water retention (Whelton et al. 2017). Finally, mineralocorticoid antagonists have a discrete diuretic action and are efficient in the treatment of SAH in patients with heart failure (Cesar et al. 2014).

Despite the existence of this range of classes of antihypertensive drugs, many of them cause side effects in some patients, which limits their use. In addition, currently, between $2 \%$ and $16 \%$ of hypertensive individuals have resistant $\mathrm{SAH}$ and do not respond satisfactorily to available treatments (Pike et al. 2017). Together, these conditions led to the use of a combination of antihypertensive drugs, which, in many cases, is not efficient. In view of this high incidence of SAH resistant to antihypertensive medication and/ or that with low adherence or tolerance to this medication, it is necessary to identify new targets and develop new drugs to ensure a better treatment of this condition (Pijacka et al. 2016).

Natural resources - The use of natural resources like leaves, flowers, peels and roots of plants for therapeutic purposes dates back thousands of years (Devienne et al. 2004). The biological activity of some plants is described in the literature as classic phytotherapies. This is the case with morphine, derived from opium extracted from the poppy (Papaver somniferum), isolated in the early $19^{\text {th }}$ century, used to control pain; caffeine, isolated in 1820 from Coffea arabica (Dutra et al. 2016), used as a stimulant; the quinine used to treat malaria and cardiac arrhythmias, isolated from species of Cinchona sp., native from the Andes, in 1819, among others (Schulz et al. 2001).

According to the WHO, "any and all plants that contain substances that can be used as therapeutic purposes or are precursors of semi-synthetic drugs in one or more organs" are called "Medicinal plants" (Geneva, 1998). Such isolated substances consist of active principles generated through the plant's natural biochemical metabolism, originating from simple and complex reactions responsible for the growth, development, and reproduction of the plant (Schaaf et al. 1995).

The primary metabolism of plants occurs through the synthesis of essential compounds for the performance of vital functions, such as the photosynthetic processes that originate the formation of fatty acids, glycolysis, the citric acid cycle, the synthesis of proteins, nucleic acids, enzymes and coenzymes, structural and genetic materials (Schaaf et al. 1995).

Secondary metabolism consists of a set of reactions apparently not essential for the survival of the species. They are characterized by a complex structure, low molecular weight, remarkable biological activities and are found in low concentrations in only certain groups of plants (Di Stasi 1995). The secondary metabolites generated are important for the 
adaptation, defense, and protection of the plant to various oscillating external environmental factors, such as seasonality, circadian rhythm, rainfall, UV radiation, atmospheric composition, altitude, temperature, micro and macro nutrients (Gobbo-Neto et al. 2007). Therefore, the accumulation and bioavailability of secondary metabolites varies according to specific needs faced by the plant (Savithramma et al. 2011).

Secondary metabolites with potential pharmacological activity are classified into alkaloids, terpenes, and phenolic compounds (Savithramma et al. 2011) and have great phytotherapy, nutraceutical and industrial value, since the producer can adapt the external conditions to obtain the metabolite of interest (Briskin 2000).

Medicinal plants with recognized antihypertensive action - Several medicinal plants are elucidated with pharmacological action in the treatment of cardiovascular disorders, including SAH. Panax ginseng and Allium sativum, for example, are described with potent vasodilating action by different systems (blocking calcium channels, NO releasing), due to the presence of hypotensive molecules such as ginsenosides, saponins and sulfur compounds (Lorenzi \& Matos 2003, Barbosa et al. 2012).

Schulz et al. (2001) and Simões et al. (2007) reported plants such as Achillea millefolium rich in artemetin, Rosmarinus officinalis with resveratrol, hydroxybenzoic acid, coumaric acid and phenolic compounds, and Cecropia pachystachya with flavones, in the antihypertensive action due to ACE inhibition.

Flavonoids, polyphenols and other compounds have also been reported in several plants such as Equisetum arvense, Viscum album, Cymbopogon citratus, Anethum graveolens, Scutiabuxifolia, Cuphea carthagenensis, Sechium edule, Echinodorus macrophyllus and Melissa officinalis, presenting important vasodilating properties application in the treatment of hypertensive cases (Mahran et al. 1991, Martins et al. 2000, Bevilaqua et al. 2001, Di Stasi et al.2002, Moraes 2004, Simões et al. 2007, Whelton et al. 2007, Conceição 2011).

It is known that Brazil is one of the countries with the greatest biodiversity in the world, and for this reason, it is characterized as an important and potent storehouse of natural resources, with about $30 \%$ of the known plant species in the world, distributed in their different ecosystems (Myers et al. 2000). Therefore, the Brazilian flora represents a potential source of phytotherapeutic agents and molecules for the development of new medicines (Gurib-Fakim 2006).

Brazilian Cerrado - The Cerrado biome is in the Central region of Brazil and covers an area of approximately 2 million $\mathrm{km}^{2}$. This biome covers the provinces of Goiás, part of Minas Gerais, Bahia and the Federal District, Tocantins, Mato Grosso, and Mato Grosso do Sul (Oliveira et al.2008), occupying around $21 \%$ of the national territory and being considered the second largest biodiversity in South America (Instituto Cerrado e Sociedade 2011). In addition, its vast extent makes it the second largest biome in Brazil, behind only the Amazon (Klink et al. 2005).

The Cerrado is characterized by a high diversity of plant and animal species and a high variety of environments (Machado et al. 2014). It has more than 10,000 species of plants, of which around 4000 of these are endemic (Scolforo \& Ferraz Filho 2013), making the Brazilian Cerrado a global hotspot, serving as the target of many research and public policies for its conservation and enhancement (Oliveira et al. 2008).

The seasonal tropical climate with dry winters and rainy summers, soils with high acidity, deficient in nutrients and rich in aluminum, and supplied by six of the eight largest hydrographic basins in Brazil (Marouelli 2003) favor the existence of such biodiversity in this region. Facing all these environmental conditions, plant species need to develop physical and physiological mechanisms to ensure their survival, the latter being the focus of this review. Secondary metabolites are physiological mechanisms of plant adaptation and are complex in structure, not linked to obtaining nutrients and energy for the cell, but rather adapting to the environment in which it is located. In this way, they are identified in variable quantities, depending on the conditions in which the plant is (Pereira \& Cardoso 2012).

A study aimed at carrying out phytochemical tests on plant species in a protected area located in the Brazilian Cerrado identified that the secondary metabolites most present in these species were tannins, alkaloids, flavonoids, and terpenes (Silva et al. 2010). These compounds already have their action recognized as antioxidants and cardiovascular protectors (Pereira \& Cardoso 2012).

Studies focused on the potential of Cerrado plants in the identification of medicinal compounds, however, are still scarce and closely related to their popular use. Over the years, a change has been sought in this scenario, with an increase in the number of studies, and with phytochemical tests of different species already available in the literature. Based on this, it is recognized that the Cerrado plants have great potential for the treatment of several diseases, including SAH (Borges 2002).

Cerrado plants with potential antihypertensive action There are reports of the antihypertensive action of some plants in the Cerrado, which point to secondary metabolites and their mechanism of action for the observed effect. Thus, it is known that mangabeira (Hancornia speciosa) has a hypotensive effect by inhibiting ACE, increasing NO levels and exhibit antioxidant action (Silva et al. 2011); gabiroba (Campomanesia xanthocarpa) exhibits dose-dependent hypotensive action by blocking AT1 receptors and acting on the autonomic nervous system (Sant'anna et al. 2017); and sangue-de-Cristo (Sabicea brasiliensis) has anti-inflammatory and antioxidant actions (Batista et al. 2014).

However, there are many other species of the Cerrado with secondary metabolites like those already studied and that have not yet been researched regarding their ability to lower blood pressure levels. These species are less known by the population and by the researchers, however they deserve attention since they present antioxidant metabolites with anti-inflammatory and hypotensive potential. After reviewing these less known species from Brazilian Cerrado and considering the concentration of secondary metabolites with potential anti-hypertensive action present in such plants, we have identified Pau-paraiba (Simarouba versicolor), Pau-santo (Kielmeyera coriacea), Abiu do cerrado (Pouteria torta), Guarandi (Calophyllum brasiliense), Bacaba (Oenocarpus bacaba), Puçá-amarelo (Mouriri elliptica), Fava-de-anta (Dimorphandramollis), Murici (Byrsonima crassifolia) and Cereja-do-cerrado (Eugenia calycina) as promising for future studies of isolation of active ingredients to be applied as alternative approaches to the treatment of SAH. The results regarding the analysis of all these plant species, considering the secondary metabolites present, their described biological activities and their potential hypotensive activity are summarized in table 1. 
Table 1. Brazilian Cerrado species with potential antihypertensive action: main metabolites, recognized medicinal action and secondary metabolites with potential hypotensive action.

\begin{tabular}{|c|c|c|c|}
\hline Plant species & $\begin{array}{c}\text { Secondary metabolites } \\
\text { described }\end{array}$ & Recognized medicinal action & $\begin{array}{l}\text { Secondary metabolites } \\
\text { with known or } \\
\text { potential hypotensive } \\
\text { action }\end{array}$ \\
\hline
\end{tabular}

$\begin{array}{lc}\begin{array}{l}\text { Pau-paraíba } \\ \text { (Simarouba } \\ \text { versicolor) }\end{array} & \begin{array}{c}\text { Quassinoids, triterpenoids, } \\ \text { mixture of steroids, a derivative } \\ \text { of squalene and the flavonoid } \\ \text { canferol (Arriaga } \text { et al. 2002) }\end{array} \\ \begin{array}{l}\text { Pau-santo } \\ \text { (Kielmeyera } \\ \text { coriacea) }\end{array} & \begin{array}{c}\text { Hydrocarbons sesquiterpenes } \\ \text { and oxygenated sesquiterpenes } \\ \text { (Martins } \text { et al. } 2015) \text {, xanthones, } \\ \text { biphenyl and triterpenes, } \\ \text { (Cortez et al. 1998) }\end{array}\end{array}$

Lupeol acetate (Perfeito et al. Abiu-do-cerrado 2005), triterpenes (Che et al. (Pouteria torta) 1980) and flavonoids (Costa et al. 2014)

Hyperine (hyperoside),

Guarandi (Calophyllum brasiliense)

Bacaba

(Oenocarpus bacaba)

Puçá-amarelo (Mouriri elliptica)

Fava-de-anta (Dimorphandra mollis)

Murici (Byrsonima crassifolia)

Cereja-do-cerrado (Eugenia calycina)

Puçá-amarelo (Mouriri elliptica) amentoflavone, quercetin, gallic acid and protocatechuic acid (Silva et al. 2001), coumarins and xanthones (Ito et al. 2003)

Polyunsaturated fatty acids (Pinto et al. 2018), phenolic compounds (Finco et al. 2012), hydroxycinnamic acids and flavonoids (Leba et al. 2016)

Terpenes, flavonoids and tannins (Andréo 2008)

Flavonoids (Petacci et al. 2010), neoisoastilbine, catechin, astilbine and tannins (Cintra et al. 2005)

Triterpenes, steroids and flavonoids (Bejar et al. 1995)

Flavonoids, fatty acids, terpenes, steroids and tannins (Ferreira et al. 2014)

Terpenes, flavonoids and tannins (Andréo 2008)
Antifungal action of its extract (Simote et al. 2006), Gonçalves et al. 2013) and HIV-1 reverse transcriptase inhibitor (Huerta-Reyes et al. 2004; César et al. 2011) antitumor action (Ghosh et al. 1977; Carvalho 2008), acetylcholinesterase enzyme (Carvalho 2008), antioxidant, antiviral, amebicidal and anti-fertility action male (Almeida et al. 2007)

Antimicrobial activity and low cytotoxicity (Martins et al. 2015), antifungal activity (Cortez et al. 1998), anti-inflammatory (Toledo et al. 2011), alpha-amylase inhibitor (Silva 2008)

Mutagenic activity (Costa et al. 2014), insecticide and antifungal (Boleti et al. 2007) and alpha-amylase inhibitor with the potential to control type 2 diabetes (Sales et al. 2017)

Analgesic action (Silva et al. 2001), cancer chemopreventive activity (Ito et al. 2003),

antiproliferative and antitumor (Ruiz-Marcial et al. 2007), antioxidant (Blanco-Ayala et al. 2013;

Antioxidant action (Mafra, 2019), rich in omega-3,6 and 9 and cardioprotective potential (Pinto et al. 2018)

Flavonoids to antioxidant and antiinflammatory action (Almeida et al. 2007)

Xanthones for the regulation of vascular tone (Peres \& Nagem 1997)

Triterpenes and

flavonoids to antioxidant and antiinflammator action

(Sales et al. 2017)

Xanthones and other polyphenols as ACE inhibitors (Braga et al. 2007).

Polyunsaturated fatty acids and flavonoids to the antioxidant and cardioprotective potential (Pinto et al. 2018)

Terpenes and flavonoids to the antioxidant

Gastroprotective, antiulcerogenic and anti-Helicobacter pylori activity (Moleiro et al. 2009), inhibition of alphaamylases and acetylcholinesterase (Silva et al. 2020)

otential and increases

the production of endogenous NO (Andréo 2008)

Insecticidal activity (Cintra et al. 2002; Cintra et al. 2005; Tavares et al. 2014), peroxidase inhibiting and ROS eliminating activity (Petacci et al. 2010)

Spasmogenic activity (Bejar et al. 1995), anti-inflammatory (Maldini et al. 2009), antidepressant (Herrera-Ruiz et al. 2011), anti-platelet aggregation action (Villar et al. 1997) and antioxidant (Moreno León 2015)

Action as antibiotic and antifungal (Ferreira et al. 2014; Sousa et al. 2015; Souza et al. 2018)

Gastroprotective, antiulcerogenic and anti-Helicobacter pylori activity (Moleiro et al. 2009), inhibition of alphaamylases and acetylcholinesterase (Silva et al. 2020)
Flavonoid with antioxidant potential (Petacci et al. 2010)

Triterpenes and flavonoids to antioxidant, anti-inflammatory and anti-platelet aggregation

(Villar et al. 1997;

Moreno León 2015)

Flavonoids and terpenes to antioxidant action (Ferreira et al. 2014)

Terpenes and flavonoids to the antioxidant potential and increases the production of endogenous NO (Andréo 2008) 


\section{Discussion}

The Brazilian Cerrado has an extensive number of plant species with potential pharmacological properties. The active compounds from the metabolism of plant species are an alternative for the treatment of several diseases, including arterial hypertension, since the presence of secondary metabolites, such as steroids, flavonoids, catechins, isoflavones, saponins, stilbenes and tannins, they can act as antioxidants, anti-inflammatories, enzyme inhibitors, channel blockers, among others. Cerrado plant species such as pau-paraíba (Simarouba versicolor), pau-santo (Kielmeyera coriacea), abiu-do-cerrado (Pouteria torta), guarandi (Calophyllum brasiliense), bacaba (Oenocarpus bacaba), puçá-amarelo (Mouriri elliptica), fava-de-anta
(Dimorphandra mollis), murici (Byrsonima crassifolia) and cereja-do-cerrado (Eugenia calycina), have many bioactive compounds that have already been studied in relation to their properties for controlling blood pressure. Figure 1 summarizes the idea of the present review, which is to point out new species from the Brazilian Cerrado that are little explored and with potential application in the development of new medicines for the treatment of systemic arterial hypertension. Therefore, future research to elucidate the mechanisms involved in a possible antihypertensive action of Cerrado plants is of fundamental importance, given the relevance of the pathology in the context of cardiovascular diseases, especially for individuals resistant to the currently available treatments.

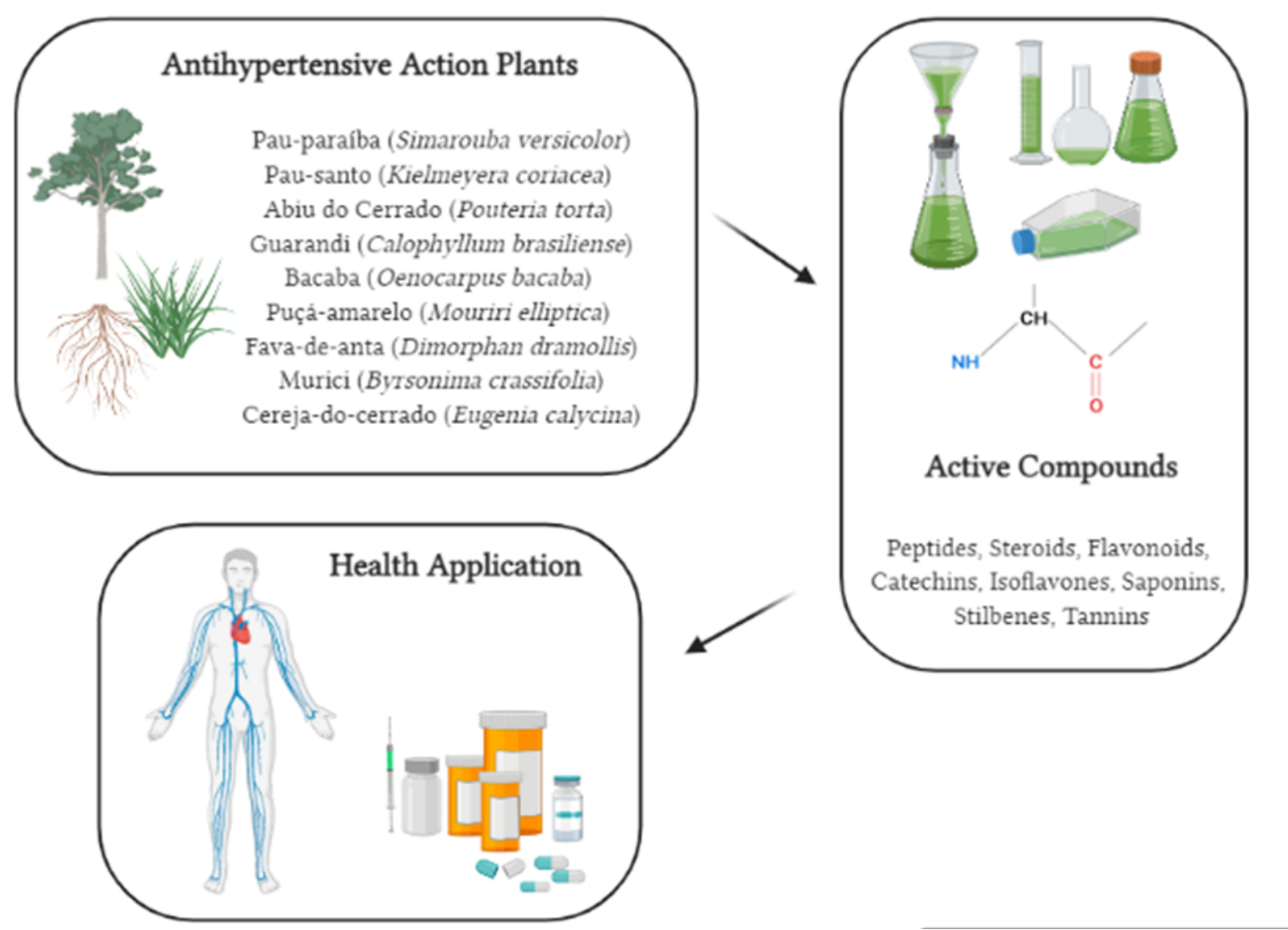

Figure 1. Scheme of Brazilian Cerrado plants identified as potential blood pressure lowering agents based on their described secondary metabolites. This figure also suggests the isolation of active compounds from these plant species and, finally, their potential application in health, especially in the field of arterial hypertension.

\section{Acknowledgements}

This work was supported by grants from Conselho Nacional de Desenvolvimento Científico e Tecnológico (CNPq) - Process: 446747/2014-9.

\section{Conflict of Interest Statement}

The authors declare no conflict of interest.

\section{Author Contributions}

Marcelo Antônio da Trindade: Substantial contribution in the concept and design of the study; Substantial contribution in the choice of articles; Contribution to data interpretation; Contribution to manuscript preparation.

Fernanda Cardoso da Silva: Substantial contribution in the choice of articles; Contribution to data interpretation; Substantial contribution to manuscript preparation. 
Bruna Juber de Araújo: Contribution to data interpretation and manuscript preparation.

Janayne Luihan Silva: Substantial contribution in the choice of articles; Contribution to data interpretation; Substantial contribution to manuscript preparation.

Thaise Gonçalves de Araújo: Contribution to critical revision, adding intellectual content.

Cristina Ribas Fürstenau: Substantial contribution to data interpretation and manuscript preparation; Contribution to critical revision, adding intellectual content; Was Marcelo Antônio da Trindade's supervisor and research coordinator.

\section{Literature cited}

Almeida, M.M.B., Arriaga, Â.M.C., Santos, A.K.L.D., Lemos, T.L., Braz-Filho, R. \& Vieira, I.J.C. 2007. Ocorrência e atividade biológica de quassinóides da últimadécada. Química Nova 30(4): 935-951.

Andreo, M.A. 2008. Prospecção químico-farmacológica em plantas superiores: estudo químico e atividade sobre o Sistema gastrintestinal de Mouriripusa Gardner e Mouriri elliptica Martius (Melastomataceae). Tese de Doutorado, Universidade Estadual Paulista, Araraquara.

Arriaga, A., de Mesquita, A.C., Pouliquen, Y.B.M., de Lima, R.A., Cavalcante, S.H., de Carvalho, M.G., de Siqueira, J.A., Alegrio, L.V. \& Braz-Filho, R. 2002. Chemical constituents of Simarouba versicolor. Anais da Academia Brasileira de Ciências 74(3): 415-424.

Barbosa, D., Nascimento, M.V.M, Lino, R.C., Magalhães, M.R., Florentino, I.F., Honório, T.C.D, Galdino, P.M, Bara, M.T.F., de Paula, J.R. \& Costa, E.A. 2012. Mechanism involved in the anti-inflammatory effect of Spiranthera odoratissima (Manacá). Revista Brasileira de Farmacognosia 22(1): 137-143.

Barroso, W.K.S., Rodrigues, C.I.S., Bortolotto, L.A., Mota-Gomes, M.A., Brandão, A.A., Feitosa, A.D.D.M. \& Nadruz, W. 2020. Diretrizes Brasileiras de Hipertensão Arterial. Arquivos Brasileiros de Cardiologia, 116: 516-658.

Batista, J.C., Santin, S.M. de O., Schuquel, I.T.A., de Arruda, L.L.M., Bersani-Amado, C.A., de Oliveira, C.M.A., Kato, L., Ferreira, H.D. \& da Silva, C.C. 2014. Constituintes químicos e avaliação das atividades antioxidante e anti-inflamatória das raízes de Sabicea brasiliensis Wernh (Rubiaceae). Química Nova 37(4): 638-642.

Bejar, E., Amarquaye, A., Che, C.T., Malone, M.H. \& Fong, H.H. 1995. Constituents of Byrsonima crassifolia and their spasmogenic activity. International Journal of Pharmacognosy 33(1): 25-32.

Bevilaqua, G.A.P., Nedel, J.L., Zuanazzi, J.A. \& Correa, C.T. 2001. Distribuição geográfica e composição química de Chapéu de couro (Echinodorus spp.) no Rio Grande do Sul. Ciência Rural 31(2): 213-218.

Blanco-Ayala, T., Lugo-Huitrón, R., Serrano-López, E.M., Reyes-Chilpa, R., Rangel-López, E., Pineda, B., Medina-Campos, O.N., Sánchez-Chapul, L.,
Pinzón, E., Trejo-Solis, C., Silva-Adaya, D., PedrazaChaverrí, J., Ríos, C., de la Cruz, V.P., Torres-Ramos, M. 2013. Antioxidant properties of xanthones from Calophyllum brasiliense: Prevention of oxidative damage induced by $\mathrm{FeSO}_{4}$. BMC Complementary and Alternative Medicine 13(1): 262.

Bloch, K.V., Klein, C.H., Szklo, M., Kuschnir, M.C.C., Abreu, G. de A., Barufaldi, L.A., da Veiga, G.V., Schaan, B. \& da Silva, T.L.N. 2016. ERICA: Prevalências de hipertensão arterial e obesidade em adolescents brasileiros. Revista de Saúde Pública 50 (Supl. 1):9s, 1-13.

Boleti, A.P.D.A. 2007. Insecticidal and antifungal activity of a protein from Pouteria torta seeds with lectin-like properties. Journal of Agricultural and Food Chemistry 55(7): 2653-2658.

Bonomini, F., Rodella, L.F., Rezzani, R. 2015. Metabolic syndrome, aging and involvement of oxidative stress. Aging and Disease 6(2):109.

Borges, C.L. 2002. Cerrado: extração da flora nativa para fins ornamentais e medicinais e o desenvolvimento sustentável. Trabalho de Conclusão de Curso, Centro Universitário de Brasília, Brasília.

Braga, F.C., Serra, C.P., Júnior, N.S.V., Oliveira, A.B., Côrtes, S.F. \& Lombardi, J.A. 2007. Angiotensinconverting enzyme inhibition by Brazilian plants. Fitoterapia 78(5): 353-358.

Briskin, D.P. 2000. Medicinal plants and phytomedicines: linking plant biochemistry and physiology to human health. Plant Physiology 124(2): 507-514.

Carvalho, J.I.X.D. 2008. Estudofitoquímico e avaliação do potencial de inibição da enzima acetilcolisnesterase de Simarouba versicolor (SIMAROUBACEAE). Dissertação de Mestrado, Universidade Federal do Ceará, Fortaleza.

Carvalho, M.H.C., Nigro, D., Lemos, V.S., Tostes, R.D.C.A. \& Fortes, Z.B. 2001. Hipertensão arterial: o endotélio e suas múltiplas funções. Revista Brasileira de Hipertensão 8(1): 76-88.

Cesar L.A., Ferreira J.F., Armaganijan D., Gowdak L.H., Mansur A.P., Bodanese, L.C., Sposito, A., Sousa, A.C., Chaves, A.J., Markman, B., Caramelli, B., Vianna, C.B., Oliveira, C.C., Meneghetti, C., Albuquerque, D.C., Stefanini, E., Nagib, E., Pinto, I.M.F., Castro, I., Saad, J.A., Schneider, J.C., Tsutsui, J.M., Carneiro, J.K.R., Torres, K., Piegas, L.S., Dallan, L.A., Lisboa, L.A.F., Sampaio, M.F., Moretti, M.A., Lopes, N.H., Coelho, O.R., Lemos, P., Santos, R.D., Botelho, R., Staico, R., Meneghello, R., Montenegro, S.T., Vaz, V.D. 2014. Diretriz de Doença Coronária Estável. Arquivos Brasileiros de Cardiologia 103(Supl. 2): 1-59.

César, G.Z.J., Alfonso, M.G.G., Marius, M.M., EstradaMuñoz, E., Contreras-Barrios, M.A., Huerta-Reyes, M., Campos-Lara, M.G., Jiménez-Estrada, M. \& Reyes-Chilpa, R. 2011. Inhibition of HIV-1 reverse transcriptase, toxicological and chemical profile of 
Calophyllum brasiliense extracts from Chiapas, Mexico. Fitoterapia 82(7): 1027-1034.

Che, C.T., Koike, K., Cordell, G.A., Fong, H.H.S. \& Dobberstein, R.H. 1980. Triterpenes of Pouteria torta (Sapotaceae). Journal of Natural Products 43(3): 420-421.

Cintra, P., Malaspina, O., Bueno, O.C., Petacci, F., Fernandes, J.B., Vieira, P.C. \& Silva, M.F. 2005. Oral toxicity of chemical substances found in Dimorphandramollis (Caesalpiniaceae) against honeybees (Apis mellifera) (Hymenoptera: Apidae). Sociobiology 45(1): 141-149.

Cintra, P., Malaspina, O., Petacci, F., Fernandes, J.B., Bueno, O.C., Vieira, P.C. \& Silva, M.F.G.F. 2002. Toxicity of Dimorphandramollis to workers of Apis mellifera. Journal of the Brazilian Chemical Society 13(1): 115-118.

Cohen, J.D. 2007.Overview of physiology, vascular biology, and mechanisms of hypertension. Journal of Managed Care \& Specialty Pharmacy 13 (5): 6-8.

Conceição, F.G.D. 2011. Efeitos anti-hipertensivos e micro circulatórios do extrato hidroalcoólico de Echinodorus grandiflorus (Chapéu de couro) em ratos espontaneamente hipertensos. Dissertação de Mestrado, Instituto Oswaldo Cruz, Rio de Janeiro.

Cortez, D.G., Young, M.C.M., Marston, A., Wolfender, J.L. \& Hostettmann, K. 1998. Xanthones, triterpenes and a biphenyl from Kielmeyera coriacea. Phytochemistry 47(7): 1367-1374.

Costa, D.L., Rinaldo, D., Varanda, E.A., de Sousa, J.F., Nasser, A.L., Silva, A.C., Baldoqui, D.C., Vilegas, W. \& dos Santos, L.C. 2014. Flavonoid detection in hydroethanolic extract of Pouteria torta (Sapotaceae) leaves by HPLC-DAD and the determination of its mutagenic activity. Journal of Medicinal Food 17(10): 1103-1112.

Devienne, K.F., Raddi, G., Pozetti, G.L. 2004. Das plantas medicinais aos fitofármacos. Revista Brasileira de Plantas Medicinais 11-14.

Di Stasi, L.C., Hiruma, C.A., Guimarães, E.M., Santos, C.D. 1994. Medicinal plants popularly used in Brazilian Amazon. Fitoterapia (Milano) 65(6): 529-540.

Dutra, R.C, Campos, M.M., Santos, A.R. \& Calixto, J.B. 2016. Medicinal plants in Brazil: Pharmacological studies, drug discovery, challenges and perspectives. Pharmacological Research 112: 4-29.

Faleiro F.G. \& Farias Neto A.L. 2008. Savanas: desafios e estratégias para o equilíbrio entre sociedade, agronegócio e recursos naturais. EMBRAPA Cerrados 505-610

Ferreira, F.P., Morais, S.R., Bara, M.T.F., Conceição, E., Paula, J.R., Carvalho, T.C., Vaz, B.G., Costa, H.B. \& Romao, W. 2014. Eugenia calycina Cambess extracts and their fractions: their antimicrobial activity and the identification of major polar compounds using electrospray ionization FT-ICR mass spectrometry.
Journal of Pharmaceutical and Biomedical Analysis 99: 89-96.

Finco, F.D.B.A., Kammerer, D.R., Carle, R., Tseng, W., Böser, S. \& Graeve, L. 2012. Antioxidant activity and characterization of phenolic compounds from bacaba (Oenocarpus bacaba Mart.) fruit by HPLC-DAD-MS. Journal of Agricultural and Food Chemistry 60(31): 7665-7673.

Förstermann, U., Xia, N. \& Li, H. 2017. Roles of vascular oxidative stress and nitric oxide in the pathogenesis of atherosclerosis. Circulation Research 120(4): 713-735.

Freitas Filho, G.A., Ferreira, E.B., Freitas, N.F., Veneziano, L.N.S., Cabral, R.M.C., Dias, R., Miranda, L.K.M., Ferreira, K.S., Silva, R.N., Ferreira, T.V. \& Cabral, F.D. 2016. Avaliação do nível de atividade física em indivíduos portadores de hipertensão arterial sistêmica da unidade de estratégia de saúde da família do município de Acreúna-GO. Revista Univap 22(40): 589-594.

Ghosh, P.C., Larrahondo, J.E., LeQuesne, P.W. \& Raffauf, R.F. 1977. Antitumor plants. IV. Constituents of Simarouba versicolor. Lloydia 40(4): 364-369.

Gobbo-Neto, L. \& Lopes, N.P. 2007. Plantas medicinais: fatores de influência no conteúdo de metabólitossecundários. Química Nova 30(2): 374-381.

Gonçalves, R.M., Lemos, C.O.T, Leal, I.C.R., Nakamura, C.V., Cortez, D.A.G., da Silva, E.A., Cabral, V.F. \& Cardozo-Filho, L. 2013. Comparing conventional and supercritical extraction of (-)-Mammea $\mathrm{A} / \mathrm{BB}$ and the antioxidant activity of Calophyllum brasiliense extracts. Molecules 18(6): 6215-6229.

Gurib-Fakim, A. 2006. Medicinal plants: traditions of yesterday and drugs of tomorrow. Molecular Aspects of Medicine 27(1): 1-93.

Harrison, D.G. \& Gongora, M.C. 2009. Oxidative stress and hypertension. Medical Clinics 93(3): 621-635.

Herrera-Ruiz, M., Zamilpa, A., González-Cortazar, M., Reyes-Chilpa, R., León, E., García, M.P., Tortoriello, J. \& Herta-Reyes, M. 2011. Antidepressant effect and pharmacological evaluation of standardized extract of flavonoids from Byrsonima crassifolia. Phytomedicine 18(14): 1255-1261.

Huerta-Reyes, M., del Carmen Basualdo, M., Abe, F., Jimenez-Estrada, M., Soler, C. \& Reyes-Chilpa, R. 2004. HIV-1 inhibitory compounds from Calophyllum brasiliense leaves. Biological and Pharmaceutical Bulletin 27(9): 1471-1475.

Ito, C., Itoigawa, M., Mishina, Y., Cechinel Filho, V., Enjo, F., Tokuda, H., Nishino, H. \& Furukawa, H. 2003. Chemical constituents of Calophyllum brasiliense. 2. Structure of three new coumarins and cancer chemopreventive activity of 4-substituted coumarins. Journal of Natural Products 66(3): 368-371.

Jankowski, V., Vanholder, R., van der Giet, M., Tölle, M., Karadogan, S., Gobom, J., Furkert, J., Oksche, A., Krause, E., Tran, T.N.A., Tepel, M., Schuchardt, M., Schlüter, H., Wiedon, A., Beyermann, M., Bader, 
M., Todiras, M., Zidek, W. \& Jankowski, J. 2007. Mass-spectrometric identification of a novel angiotensin peptide in human plasma. Arteriosclerosis, Thrombosis, and Vascular Biology 27(2): 297-302.

Klink, C.A. \& Machado, R.B. 2005. A conservação do Cerrado Brasileiro. Megadiversidade 1(1): 147-155.

Kohlmann Jr, O., Guimarães, A.C., Carvalho, M.H.C., Chaves Jr, H.de C., Machado, C.A., Praxedes, J.N. \& Santello, J.L. 1999. III Consenso Brasileiro de hipertensão arterial. Arquivos Brasileiros de Endocrinologia \& Metabologia 43(4): 257-286.

Krieger, E.M., Franchini, K.G.\& Krieger, J.E. 1996. Fisiopatogenia da hipertensão arterial. Medicina, Ribeirão Preto. 29: 181-192.

Leba, L.J., Brunschwig, C., Saout, M., Martial, K., Bereau, D. \& Robinson, J.C. 2016. Oenocarpus bacaba and Oenocarpus bataua leaflets and roots: A new source of antioxidant compounds. International Journal of Molecular Sciences 17(7): 1014.

Li, W-J., Liu, Y., Wang, J-J., Zhang, Y-L., Lai, S., Xia, Y-L., Wang, H-X. \& Li, H-H. 2016. “Angiotensin II memory" contributes to the development of hypertension and vascular injury via activation of NADPH oxidase. Life Sciences 149: 18-24.

Li, Z., Fu, C., Yang, F. \& Mao, Z. 2018. Prevalence and risk factors of hypertension for the middle-aged population in China - results from the China Health and Retirement Longitudinal Study (CHARLS). Clinical and Experimental Hypertension 41(1): 80-86.

Lijnen, P.J., Petrov, V.V. \& Fagard, R.H. 2001. Angiotensin II-induced stimulation of collagen secretion and production in cardiac fibroblasts is mediated via angiotensin II subtype 1 receptors. Journal of the ReninAngiotensin-Aldosterone System 2(2): 117-122.

Lima, S.G.D., Hatagima, A. \& Silva, N.L.C.L.D. 2007. Sistema renina-angiotensina: é possível identificar genes de suscetibilidade à hipertensão? Arquivos Brasileiros de Cardiologia 89(6): 427-433.

Lorenzi, H. \& Matos, F.J. 2003. Plantas medicinais no Brasil: nativas e exóticas. 1. ed. Instituto Plantarum, Nova Odessa, SP.

Machado, R.B., Ramos Neto, M.B., Pereira, P.G.P., Caldas, E.F., Gonçalves, D.A., Santos, N.S.,

Mafra, V.R. 2019. Potencialfarmacológico e toxicológico da mutamba (Guaxumaulmifolia) e da bacaba (Oenocarpus bacaba). Disponível em http://hdl.handle. net/11612/1515 (acesso em 01-IV-2018).

Mahran, G.H., El-Fishawy, A.M., Hosny, A.M.S. \& Hilal, A.M. 1991. Phytochemical and antimicrobial study of Jacaranda mimosaefolia D. Don. grown in Egypt. Herba-Hungarica 30: 98-108.

Malachias, M.V.B., Souza, W.K.S.B., Plavnik, F.L., Rodrigues, C.I.S., Brandão, A.A., Bortolotto, L.A., Franco, R.J.S., Poli-de-Figueiredo, C.E., Jardim, P.C.B.V., Amodeo, C., Barbosa, E.C.D., Koch, V., Gomes, M.A.M., Paula, R.B., Póvoa, R.M.S., Colombo, F.C., Ferreira Filho, S., Miranda, R.D.,
Machado, C.A., Nobre, F., Nogueira, A.R., Mion Júnior, D., Kaiser, S., Forjaz, C.L.M., Almeida, F.A., Martim, J.F.V., Sass, N., Drager, L.F., Muxfeldt, E., Bodanes, L.C., Feitosa, A.D., Malta, D., Fuchs, S., Magalhães, M.E., Oigman, W., Moreira Filho, O., Pierin, A.M.G., Feitosa, G.S., Bortolotto, M.R.F.L., Magalhães, L.B.N.C., Silva, A.C.S., Ribeiro, J.M., Borelli, F.A.O., Gus, M., Passarelli Júnior, O., Toledo, J.Y., Salles, G.F., Martins, L.C., Jardim, T.S.V., Guimarães, I.C.B., Antonello, I.C., Lima Júnior, E., Matsudo, V., Silva, G.V., Costa, L.S., Alessi, A., Scala, L.C.N., Coelho, E.B., Souza, D., Lopes, H.F., Gowdak, M.M.G., Cordeiro Júnior, A.C., Torloni, M.R., Klein, M.R.S.T., Nogueira, P.K., Lotaif, L.A.D., Rosito, G.B.A., Moreno Júnior, H. 2016. $7^{\text {a }}$ Diretriz Brasileira de Hipertensão Arterial. Arquivos Brasileiros de Cardiologia 107(Supl. 3): 1-83.

Maldini, M., Sosa, S., Montoro, P., Giangaspero, A., Balick, M.J., Pizza, C. \& Della Loggia, R. 2009. Screening of the topical anti-inflammatory activity of the bark of Acacia cornigera Willdenow, Byrsonima crassifolia Kunth, Sweetia panamensis Yakovlev and the leaves of Sphagneti colatrilobata Hitchcock. Journal of Ethnopharmacology 122(3): 430-433.

Marouelli, R.P. 2003. O desenvolvimento sustentável da agricultura no cerrado brasileiro. Monografia de Especialização, Faculdade Getúlio Vargas, Brasília.

Martins, C. de M., do Nascimento, E.A, de Morais, S.A.L., de Oliveira, A., Chang, R., Cunha, L.C.S., Martins, M.M., Martins, C.H.G, Moraes, T.daS., Rodrigues, P.V., da Silva, C.V. \& de Aquino, F.J.T. 2015. Chemical constituents and evaluation of antimicrobial and cytotoxic activities of Kielmeyera coriacea Mart. \&Zucc. essential oils. Evidence-Based Complementary and Alternative Medicine 2015:1-9.

Martins, E.R., Castellani, J. \& Dias, E. 2000. Plantas medicinais. Viçosa: UFV.

Mendes, G.S., Moraes, C.F. \& Gomes, L. 2014. Prevalência de hipertensão arterial sistêmica em idosos no Brasil entre 2006 e 2010. Revista Brasileira de Medicina de Família e Comunidade 9(32): 273-278.

Moleiro, F.C., Andreo, M.A., dos Santo, R.deC., Moraes, T.deM., Rodrigues, C.M., Carlic, C.B.de A., Lopes, F.C.M, Pellizzon, C.H., Carlos, I.Z., Vilegas, T.M.B.W \& Hiruma-Lima, C.A. 2009. Mouriri elliptica: validation of gastroprotective, healing and anti-Helicobacter pylori effects. Journal of Ethnopharmacology 123(3): 359-368.

Moneer, Z., Dyer, J.L. \& Taylor, C.W. 2003. Nitric oxide coordinates the activities of the capacitative and non-capacitative $\mathrm{Ca} 2+$-entry pathways regulated by vasopressin. Biochemical Journal 370(2): 439-448.

Moraes, M.O., Bezerra, F.A.F., Lotufo, L.C., Pessoa, C. \& Moraes, M.E.A. 2004. Avaliação clínica da eficácia e segurança de fitoterápicos no Brasil. Arquivos Brasileiros de Fitomedicina Científica 1: 30-39. 
Moreno León, G.R. 2015. Evaluación in vitro de la capacidad antioxidante del extracto del fruto de nanche (Byrsonima crassifolia). Maestria en Ciencias Alimentarias, Universidad Veracruzana, Xalapa.

Myers, N., Mittermeier, R.A., Mittermeier, C.G., Fonseca, G.A. \& Kent, J. 2000. Biodiversity hotspots for conservation priorities. Nature 403(6772): 853-858.

Oigman, W. 2014. Sinais e sintomas em hipertensão arterial. JBM 102(5): 13-18.

Oliveira, D.A., Pietrafesa, J.P. \& Silva Barbalho, M.G. 2008. Manutenção da biodiversidade e o hotspot Cerrado. Caminhos de Geografia 9(26): 101-114.

Pereira, R.J. \& Cardoso, M.G. 2012. Metabólitos secundários vegetais e benefícios antioxidantes. Journal of Biotechnology and Biodiversity 3(4): 146-152.

Peres, V. \& Nagem, T.J. 1997. Trioxygenated naturally occurring xanthones. Phytochemistry 44(2): 191-214.

Petacci, F., Freitas, S.S., Brunetti, I.L. \& Khalil, N.M. 2010. Inhibition of peroxidase activity and scavenging of reactive oxygen species by astilbin isolated from Dimorphandramollis (Fabaceae, Caesalpinioideae). Biological Research 43(1): 63-74.

Pijacka, W., Moraes, D.J.A, Ratcliffe, L.E.K, Nightingale, A.K., Hart, E.C., da Silva, M.P., Machado, B.H., McBryde, F.D., Abdala, A.P., Ford, A.P. \& Paton, J.F.R. 2016. Purinergic receptors in the carotid body as a new drug target for controlling hypertension. Nature Medicine 22(10): 1151-1159.

Pike, E., Fagerlund, B.C., Giske, L., Desser, A. \& Harboe, I. 2017. Baroreflex Activation Therapy for Drug-Resistant Hypertension: A Single Technology Assessment [Internet]. Report from the Norwegian Institute of Public Health No. 2017-17, Oslo - Norway. PMID: 29553677.

Pinto, R.H.H., Sena, C., Santos, O.V., Costa, W.A., Rodrigues, A.D.C. \& Junior, R.C. 2018. Extraction of bacaba (Oenocarpus bacaba) oil with supercritical $\mathrm{CO}_{2}$ : Global yield isotherms, fatty acid composition, functional quality, oxidative stability, spectroscopic profile and antioxidant activity. Grasas y Aceites 69(2): 246.

Piotrkowski, B., Calabró, V., Galleano, M. \& Fraga, C.G. 2015. Epicatechin prevents alterations in the metabolism of superoxide anion and nitric oxide in the hearts of L-NAME-treated rats. Food \& Function 6(1): 154-160.

Précoma, D.B., de Oliveira, G.M.M., Simão, A.F., Dutra, O.P., Coelho, O.R., Izar, M.C.O, Póvoa, R.M.S., Giuliano, I.C.B., de Alencar Filho, A.C., Machado, C.A., Scherr, C., Fonseca, F.A.H., dos Santos Filho, R.D., de Carvalho, T., Avezum Jr., A., Esporcatte, R., Nascimento, B.R., Brasil, D.P., Soares, G.P., Villela, P.B., Ferreira, R.M., Martins, W.A., Sposito, A.C., Halpern, B., Saraiva, J.F.K., Carvalho, L.S.F., Tambascia, M.A., Coelho-Filho, O.R., Bertolami, A., Correa Filho, H., Xavier, H.T., Faria Neto, J.R., Bertolami, M.C., Giraldez, V.Z.R., Brandão, A.A., Feitosa, A.D.M., Amodeo, C., de Souza, D.S.M.,
Barbosa, E.C.D., Malachias, M.V.B, de Souza, W.K.S.B., da Costa, F.A.A., Rivera, I.R., Pellanda, L.C., da Silva, M.A.M, Achutti, A.C., Langowiski, A.R., Lantiere, C.J.B., Scholz, J.R., Ismael, S.M.C., Ayoub, J.C.A., Scala, L.C.N., Neves, M.F., Jardim, P.C.B.V., Fuchs, S.C.P.C., Jardim, T.S.V., Moriguchi, E.H., Schneider, J.C., Assad, M.H.V., Kaiser, S.E., Lottenberg, A.M., Magnoni, C.D., Miname, M.H., Lara, R.S., Herdy, H.A., de Araújo, C.G.S., Milani, M., da Silva, M.M.F., Stein, R., Lucchese, F.A., Nobre, F., Griz, H.B., Magalhães, L.B.N.C., de Borba, M.H.E, Pontes, M.R.N, Mourilhe-Rocha, R. 2019. Atualização da Diretriz de Prevenção Cardiovascular da Sociedade Brasileira de Cardiologia. Arquivos Brasileiros de Cardiologia 113(4): 787-891.

Rajagopalan, S., Kurz, S., Münzel, T., Tarpey, M., Freeman, B.A., Griendling, K.K. \& Harrison, D.G. 1996. Angiotensin II-mediated hypertension in the rat increases vascular superoxide production via membrane NADH/NADPH oxidase activation. Contribution to alterations of vasomotor tone. Journal of Clinical Investigation 97(8): 1916-1923.

Roy, C., Tabiasco, J., Caillon, A., Delneste, Y., Merot, J., Favre, J., Guihot, A.L., Martin, L., Nascimento, D.C., Ryffel, B., Robson, S.C., Sévigny, J., Henrion, D. \& Kauffenstein, G. 2018. Loss of vascular expression of nucleoside triphosphate diphosphohydrolase-1/CD39 in hypertension. Purinergic Signalling 14(1): 73-82.

Ruiz-Marcial, C., Chilpa, R.R., Estrada, E., ReyesEsparza, J., Fariña, G.G. \& Rodríguez-Fragoso, L. 2007. Antiproliferative, cytotoxic and antitumour activity of coumarins isolated from Calophyllum brasiliense. Journal of Pharmacy and Pharmacology, 59(5): 719-725.

Sales, P.M., de Souza, P.M., Dartora, M., Resck, I.S., Simeoni, L.A., Fonseca-Bazzo, Y.M., Magalhães, P.O. \& Silveira. D. 2017. Pouteria torta epicarp as a useful source of $\alpha$-amylase inhibitor in the control of type 2 diabetes. Food and Chemical Toxicology 109: 962-969.

Savithramma, N., Rao, M.L. \& Suhrulatha, D. 2011. Screening of medicinal plants for secondary metabolites. Middle-East Journal of Scientific Research 8(3): 579-584.

Schaff, J., Walter, M.H. \& Hess, D. 1995. Primary metabolism in plant defense. Plant Physiology 108: 949-960.

Schulz, V., Hänsel, R. \& Tyler, V.E. 2001. Medicinal plants, phytomedicines, and phytotherapy. Rational Phytotherapy 1-39.

Scolforo, J.R.S. \& Ferraz Filho, A.C. 2013. A Expansão Florestal Brasileira: Desafios e Perspectivas. 1ed. Suprema, Lavras, MG.

Silva, E.M. 2008. Açãoinibitória de extratos de plantas do Cerrado sobre $\alpha$-amilases com ênfase em Kielmeyera coriacea. Dissertação de Mestrado, Universidade de Brasília, Brasília.

Silva, G.C., Braga, F.C., Lima, M.P., Pesquero, J.L., Lemos, V.S. \& Cortes, S.F. 2011. Hancornia speciosa Gomes induces hypotensive effects through 
inhibition of ACE and increase on NO. Journal of Ethnopharmacology 137(1): 709-713.

Silva, K.L., Santos, A.R., Mattos, P.E., Yunes, R.A., DelleMonache, F. \& Cechinel-Filho, V. 2001. Chemical composition and analgesic activity of Calophyllum brasiliense leaves. Therapie 56(4): 431-434.

Silva, L.S., Porfiro, C.A., Silva, F.G., Santos Rodrigues, A.R. \& Pereira, P.S. 2020. Acetylcholinesterase and $\alpha$-Amylase inhibitors from Mouriri elliptica Martius leaf extract. Bioscience Journal 36(2): 578-590.

Silva, N.L.A., Miranda, F.A.A. \& Conceição, G.M. 2010. Triagem fitoquímica de plantas de Cerrado, da área de proteção ambiental municipal do Inhamum, Caxias, Maranhão. Scientia Plena 6(2): 1-17.

Simões, C.M.O., Schenkel, E.P., Petrovick, P.R., Gosmann, G., de Mello, J.C.P. \& Mentz, L.A. 2007. Farmacognosia: do produto natural ao medicamento. 6ed. Editora da UFSC, Florianópolis, SC.

Simote, S.Y. 2006. Estudo fitoquímico de Heliettapuberula (Rutaceae), Simarouba versicolor (Simaroubaceae) e busca de um processo de microencapsulação de compostos ativos visando o controle de formigas cortadeiras. Tese de Doutorado, Universidade Federal de São Carlos, São Carlos.

Sinha, N. \& Kumar Dabla, P. 2015. Oxidative stress and antioxidants in hypertension-a current review. Current Hypertension Reviews 11(2): 132-142.

Sousa, R.M.F., de Morais, S.A.L., Vieira, R.B.K., Napolitando, D.R., Guzman, V.B., Moraes, T.S., Cunha, L.C.S., Martins, C.H.G., Changa, R., de Aquino, F.J.T., do Nascimento, E.A. \& de Oliveira, A. 2015. Chemical composition, cytotoxic, and antibacterial activity of the essential oil from Eugenia calycina Cambess. leaves against oral bacteria. Industrial Crops and Products 65: 71-78.

Souza, A.M., Oliveira, C.F., Oliveira, V.B., Betim, F.C.M., Miguel, O.G. \& Miguel, M.D. 2018. Traditional uses, Phytochemistry, and antimicrobial activities of Eugenia species-a review. Planta Medica 84(17): 1232-1248.

Tabor, K. \& Steininger, M. 2004. Estimativas de perda da área do Cerrado brasileiro. Relatório
Tavares, W.D.S., Pereira, A.I.D.A., Freitas, S.D.S., Serrão, J.E. \& Zanuncio, J.C. 2014. The chemical exploration of Dimorphandramollis (Fabaceae) in Brazil, with emphasis on insecticidal response: A review. Journal of Scientific \& Industrial Research 73: 465-468.

Relatório Técnico não publicado. Disponível em http:// cmbbc.cpac.embrapa.br/RelatDesmatamCerrado $\% 20$ CIBrasil\%20JUL2004.pdf (acesso em 01-IV-2018).

Toledo, C.E., Britta, E.A., Ceole, L.F., Silva, E.R., de Mello, J.C.P., Dias Filho, B.P., Nakamura, C.V. \& Ueda-Nakamur, T. 2011. Antimicrobial and cytotoxic activities of medicinal plants of the Brazilian cerrado, using Brazilian cachaça as extractor liquid. Journal of Ethnopharmacology 133(2): 420-425.

Villar, R., Calleja, J.M., Morales, C. \& Cáceres, A. 1997. Screening of 17 Guatemalan medicinal plants for platelet antiaggregant activity. Phytotherapy Research: An International Journal Devoted to Medical and Scientific Research on Plants and Plant Products 11(6): 441-445.

Whelton, P.K., Carey, R.M., Aronow, W.S., Casey Jr, D.E., Collins, K.J., Himmelfarb, C.D., DePalma, S.M., Gidding, S., Jamerson, K.A., Jones, D.W., MacLaughlin, E.J., Muntner, P., Ovbiagele, B. Smith Jr, S.C., Spencer, C.C., Stafford, S.S., Taler, S.J., Thomas, R.J., Williams Sr, K.A., Williamson, J.D., Wright Jr, J.T. 2017. Guideline for the prevention, detection, evaluation, and management of high blood pressure in adults: a report of the American College of Cardiology/American Heart Association Task Force on Clinical Practice Guidelines. Journal of the American College of Cardiology 71(19): 127-248.

World Health Organization. 1998. Regulatory situation of herbal medicines: a worldwide review Disponível em https://apps.who.int/iris/bitstream/handle/10665/63801/ WHO_TRM_98.1.pdf (acesso em 01-IV-2018).

Recebido: 04/12/2020

Aceito: 06/10/2021

Editor Associado: Wagner Ferreira 